\title{
JESUS THE ONLY TEACHER
}

\section{Samuel Byrskog 1}

This study investigates the relationship between the understanding of Jesus as the only teacher and the transmission of the Jesus tradition in the Matthean community. The phenomena of transmission in the Matthean community are seen within a field of continuity relating to the past and to the future of their socio-cultural situation. The analysis falls therefore into two parts, the first of which attempts to reconstruct Matthew's socio-cultural situation of transmission manifested in ancient Israel and ancient Judaism. The investigation seeks thereby to avoid moulding the Matthean transmission into schemata reflecting a cultural matrix foreign to Matthew himself.

The two parts of the investigation are structured in accordance with three basic issues of main interest. The first one deals with how the transmitters thought of their own setting of transmission. The study asks about the existence of settings in which the authority of a person considered to be a teacher constituted the essential identity marker of the transmitting group.

The second issue concerns motives of transmission relating to the transmitters' understanding of the teacher-'person oriented motives of transmission.' These motives are distinguished from motives created by various general and practical activities and needs in the communities. Three non-practical motives emerge: (1) a didactic motive in which the teaching was an entity independent of the life and the status of the teacher, (2) a didactic-biographical motive in which the teaching was an entity integrated within the life of the teacher and

1Samuel Byrskog, Jesus the Only Teacher: Didactic Authority and Transmission in Ancient Israel, Ancient Judaism and the Matthean Community (Coniectanea Biblica: New Testament Series 24; Stockholm: Almqvist \& Wiksell International 1994). PhD Thesis Lund University, Sweden; supervisor: professor Birger Gerhardsson. 
(3) a didactic labelling motive in which the teaching was an entity integrated within a process that enhanced the teacher to an exclusive status of authority by means of validating labels. The study asks specifically to what extent the two latter motives interacted with the former during the transmission.

The third issue asks about the correlation between the setting determined by didactic authority and the personoriented motives of transmission on the one hand, and the actual process of transmission on the other-the 'personal specificity' of transmission. The study seeks for a correlation in three areas: (1) the identification of traditions, (2) the (oral and written) means of transmission and (3) the preservation and elaboration of traditions.

It becomes evident, as the main result, that the dominating notion of Jesus as the only teacher in Matthew's gospel narrative has decisively affected the transmission of the Jesus tradition in the Matthean community. The study establishes the existence of a separate setting exhibiting non-practical motives of transmission which correlated with the way the Jesus tradition actually was preserved and elaborated. The transmitters regarded themselves as pupils of no one else but Jesus, the only teacher, and defined their own setting of transmission as the school of Jesus. Accordingly, they transmitted because they cherished Jesus' teaching, life and person for their own sake; they were not left only to immediate consideration about the present and the future activities and needs of the community. Their personal involvement in the 'inner' core of the tradition correlated with a transmission process that enhanced Jesus to an exclusive didactic status of authority, both through preservation and elaboration of the Jesus tradition.

The present study also implies that the transmitters were highly able and motivated to preserve the tradition faithfully in spite of their own and the community's creative activities, and it emphasizes the need to analyze the technical matters of transmission together with an appreciation of the transmitters' own environment and convictions. As a further corollary, broad phenomenological patterns of transmission, with possible repercussions for further study, emerge. 